\title{
The Innovative Model for the Formation of a Database Used to Assess a System of Economic Security of Retail Companies
}

\author{
M. Chorna ${ }^{1}$, O. Shumilo ${ }^{2} \&$ H. Zabrodska ${ }^{3}$ \\ 1 Department of Economics of Catering and Trade Enterprises, Kharkiv State University of Food Technology and \\ Trade, Kharkov, Ukraine \\ ${ }^{2}$ Department of Finances and Credit, Kharkiv National University of Construction and Architecture, Kharkov, \\ Ukraine \\ ${ }^{3}$ Department of Foreign Trade and Tourism, Kharkiv State University of Food Technology and Trade, Kharkiv, \\ Ukraine
}

Correspondence: M. Chorna, Doctor of Economic Sciences, Professor, Department of Economics of Catering and Trade Enterprises, Kharkiv State University of Food Technology and Trae, Kharkov, Ukraine. E-mail: mv.1008@gmail.com

Received: November 5, 2019

Accepted: November 15, 2019

Online Published: December 22, 2019

doi:10.5430/rwe.v10n4p23

URL: https://doi.org/10.5430/rwe.v10n4p23

\begin{abstract}
The article highlights topicality of an issue related to assessing economic security of retail companies, which face hazards and threats under contemporary unstable economic conditions, for making decisions concerning ensuring a high level of the economic security, efficiency, and sustainable development of a company in general. The authors have developed a model of forming a database for assessing economic security of retail companies using mathematical modelling in order to avoid difficulties in the process of forming the database. Application of mathematical methods enables to create the more informative database, which will be used to conduct a more thorough analysis. This allows to make effective managerial decisions regarding ensuring a high level of economic security of a retail company. A methodical tool of M. Pohozhykh and M. Safronova underlies the model of forming the database for assessing economic security of a retail company applying methods of mathematical modelling. The methodical tool consists in modelling an $n$-dimensional geometric shape, namely a $n$ - dimensional parallelepiped, taking into account properties of the Euclidean space. The model of forming the database for conducting an assessment is an outcome of the scientific research.
\end{abstract}

Keywords: assessment, database, economic security, optimization models, retailing

\section{Introduction}

Nowadays, retail companies function under unsustainable and dynamic economic conditions. Therefore, an issue of assessing a level of economic security of a company is of particular importance. Results of an assessment enables managers to make managerial decisions regarding ensuring a high level of economic security of a retail company, its efficiency, and sustainable development of a company in general.

A dataset, which contains several indicators being formed according to models of the presentation, underlies a process of obtaining reliable estimates. Thus, there is a need to research a matter of implementing a contemporary method for the formation of the database used to assess a level of economic security of retail companies.

The formation of the database for examining economic processes is grounded in certain methods, particularly expert evaluation, indicator, and matrix methods. Domestic and foreign scientists, namely S. Illiashenko (2003), R. Datskiv (2004), B. Greer (1986), V. Babenko (2013, 2017, 2018), N. Vnukova (2002), S. Dovbnia and N. Hichova (2008), A. Tkachenko and O. Reznikov (2010), V. Kovalenko (2016), et al., have applied the mentioned methods for the formation of the database in the process of assessing economic security of a company. Regardless of the considerable amount of scientific papers, an issue of the formation of the database used to assess a system of economic security of retail companies requires further examination.

Intensification of the current market processes leads to rapid expansion of methods of mathematical modelling. The use of these methods fosters enhancing economic analysis, which increases efficiency of companies in different sectors, 
including retail companies (Shorikov, 2014), (Maliarets, 2017).

Mathematical methods and models allow systematizing economic information, indicating disadvantages in current information, and developing requirements to preparation of new information or correction of current data. Development and application of mathematical models conduce to determination of ways for improving a system of economic information oriented towards accomplishment of particular goals (Totsenko, 2002).

\section{Materials and Methods}

The authors have developed the model for the formation of the database used to assess a system of economic security of retail companies, using mathematical modelling. The model for the formation of the database used to conduct an assessment is an outcome of scientific research.

The authors have experienced difficulties related to the formation of the database in the process of assessing a level of economic security of retail companies. These difficulties are caused by a large amount of data and the repeating value of a numerical expression of different economic indicators. To form the database used to determine a level of economic security of a company, the authors propose to apply mathematical methods. Application of these methods enables to form a more informative database, which may be used to conduct a more thorough analysis. This will allow making effective managerial decisions regarding ensuring a high level of economic security of a retail company.

The methodical instrument of M. Pohozhykh and M. Safronova best corresponds to the article's purpose among a significant number of mathematical models for the presentation of information (Pohozhykh and Safronova, 2018). This instrument is based on modelling a $n$-dimensional shape, namely a $n$-dimensional parallelepiped, and takes into account properties of Euclidean space. The above-mentioned scientists apply the model for the formation of databases for problems of optimum planning activity of a company. The considered methodical instrument is adapted for the formation of the database used to assess a system of economic security of retail companies.

The scientists have proposed to apply an aggregate criterion - an integral indicator and expanded system of local indicators (by functional components of economic security) - to assess a system of economic security at a retail company (Shumilo, 2015). The authors propose to mark a general level of economic security at an enterprise with the value $A$. The general level is described by $n$ indicators $A i, i=1,2, \ldots, n$. Economic security of a retail company as a system consists of determined $m$ discrete elements (functional components of economic security - financial, market, commodity, intellectual, personnel, technical, technological, political, legal, and information security) $a_{j}, j=1,2, \ldots$ $m$, i.e. $A=\sum^{m} a_{j}$. A level of economic security in terms of each functional component $a_{j}$ is expressed by $n$ indicators $a_{j i}$, at the same time respective $i$ indicators of all the $m$ components have a common purpose $i=1,2, \ldots n$. Since the indicators of each functional component of economic security by units of measurement (i.e. the indicator as well as

$a_{j}$ and $A$ are expressed in terms of the same unit of measurement) are homogenous (they are measured in terms of monetary units $\mathrm{x}$ - hryvnia, the United State dollar, or another unit), we have the following conditions:

1) $a_{j}=\sum_{i=1}^{n} a_{j i}$;

2) $\forall j \in\{1,2, \ldots, m\}: a_{j i} \in A_{i}, i=1,2, \ldots, n$ (i.e. units of measurement of $a_{j i}$ and $A_{i}$ coincide);

3) $A=\sum_{i=1}^{n} A_{i}$;

4) $A=\sum_{j=1}^{m} \sum_{i=1}^{n} a_{j i}$ (a "floating ruler" model).

A level of economic security of a retail company is determined in terms of monetary units (hryvnias) because the scientists have proven its embodiment in a turnover ratio, which is also expressed in terms of hryvnias.

The authors face an economic problem concerned with a necessity of the formation of the database used to assess economic security in a retail sector. To fulfill this goal, the authors have structured economic security by functional components and taken in account units of measurement for the indicators.

To solve the problem related to determination of the general indicator of a level of economic security at a company, the authors propose to select the local indicators (by functional components), which are expressed in terms of the same units.

Applying geometric projection methods (Stoyan and Yakovlev, 1986; Sadkovyi et al., 2008; Komyak et al., 2012; Verkhoturov and Petrenko, 2005; Hrebennik et al., 2004), namely methods for positioning $n$-parallelepipeds 
proposed by Ye. Mukhacheva and V. Kartak (Chub and Novozhylova, 2002; Novozhylova and Chernomorets, 1992; Hil et al., 1995; Stoian et al., 1998; Yevseieva et al., 1999), the authors have conducted mathematical modelling of the economic problem through the presentation of each functional component of economic security at a company in the form of a rectangular $n$ - dimensional parallelepiped. Simultaneously, the general indicator is also presented in the form of a rectangular $n$-dimensional parallelepiped consisting of a set of parallelepipeds built according to the components of economic security (Mukhacheva et al., 2000). The model has been built according to the following stages:

1. The correlation of the set of indicators by each functional component aji $(\mathrm{a} 0 \mathrm{i}), \mathrm{j}=1,2, \ldots, \mathrm{m} ; \mathrm{i}=1,2, . ., \mathrm{n}$, with axes of a Cartesian coordinate system of Euclidean space $R^{n}$.

2. The presentation of the functional components of economic security $a_{j}, j=1,2, \ldots, m$, in the form of $n$-dimensional parallelepipeds (a $n$-parallelepiped):

$$
P_{j}=\left\{y_{i}=\left(y_{j 1}, y_{j 2}, \ldots, y_{j n}\right) \in R^{n}: 0 \leq y_{j i} \leq b_{j i}, i=1,2, \ldots, n\right\},
$$

where $b_{j i}=k j i x_{j i}, x_{j i}=a_{j i}$

3. Building a $n$-parallelepiped ( $\mathrm{P} 0$ ), which expresses a level of economic security at a company determined by the measured value $A$.

$$
P_{0}=\left\{y=\left(y_{01}, y_{02}, \ldots, y_{0 n}\right) \in R^{n}: 0 \leq y_{0 i} \leq b_{0 i}, i=1,2, \ldots, n\right\},
$$

where $b 0 i=k 0 i x 0 i, x 0 i=a 0 i=A i$

At the same time, all the objects are equally oriented and their rotations are eliminated.

\section{Results and Discussions}

Taking into consideration the above-mentioned requirements of Euclidean space and homogeneity of space (i.e. density $p=$ const $), A$ is presented as:

$$
A=p_{A} V_{A},
$$

where $p A$ - density, $V A$ - the volume of a $n$-dimensional shape. In this case

$V_{A}=k_{01} x_{01} k_{02} x_{02} \ldots k_{0 n} x_{0 n}=\prod_{i=1}^{n} k_{0 i} x_{0 i}$ - volume of the $n$-parallelepiped $P 0$ with sizes of one-

dimensional edges $k 0 i x 0 i, i=1,2, \ldots, n$.

The geometrical essence of such operation is to transform lengths of the segment into the volume of $n$ - dimensional parallelepiped. The economic essence consists in the presentation of a set of data characterizing economic security of a company in the form of a $n$-dimensional parallelepiped.

Thus

$$
x_{01}+x_{02}+\cdots+x_{0 n}=p_{A} k_{01} x_{01} k_{02} x_{02} \ldots k_{0 n} x_{0 n} \text { or } \sum_{i=1}^{n} x_{0 i}=p_{A} \prod_{i=1}^{n} k_{0 i} x_{0 i}
$$

The geometric expression of initial density pj for all the $m$ components will be the same: $p j=p A=p, j=1,2, \ldots, m$.

Therefore, each component $a_{j}=\sum_{l=1}^{n} a_{j i}, \mathrm{j}=1,2, \ldots, \mathrm{m}, \quad$ may be presented in such form: $a_{j}=p V_{j}$,

Where $V_{j}=k_{j 1} x_{j 1} k_{j 2} x_{j 2} \ldots k_{j n} x_{j n}=\prod_{j-1}^{n} k_{j i} x_{j i}$-volume of the $n$-parallelepiped $P j$ with sizes of one- dimensional edges $k_{j i} x_{j i}, i=1,2, \ldots, n$.

That is to say, $x_{j 1}+x_{j 2}+\cdots+x_{j n}=p k_{j 1} x_{j 1} k_{j 2} x_{j 2} \ldots k_{j n} x_{j n}$ or $\sum_{i=1}^{n} x_{j i}=p \prod_{l=1}^{n} k_{j i} x_{j i}$.

It is worth mentioning that the value $A$ (a level of economic security of a company) equals a product of density and a sum of volumes of the $n$-parallelepipeds $P j$ (the functional components of economic security of a company) $j=1,2, \ldots, m$, i.e. $A=p \sum^{m} k_{j 1}$ 
Conditionality of the volume $V A$, of the $n$-parallelepiped for the general level of economic security and $V j, j=1,2, \ldots$, of the $n$-parallelepipeds (by the components of economic security) is ensured by coefficients $k 0 i(k j i), i=1,2, \ldots, n$,

namely their dimensionality:

$$
\left[k_{01}\right]\left(\left[k_{j i}\right]\right)=\frac{\text { arbitrary units }}{\text { units of measurement } A}, i=1,2, \ldots, n \text {; }
$$

$$
\left[V_{A}\right]\left(\left[V_{j}\right]\right)=(\text { arbitrary units })^{3} \text {. }
$$

Moreover,

$$
[p]=\frac{\text { units of measurement } A}{\text { (arbitrary units) }} \text {. }
$$

There is a need to notice that $p=$ const is a necessary term for solving the problem, economic interpretation of which consists in the formation of data expressed in terms of the same units of measurement. Additional conditions are as follows:

1) $k_{j 1}=k_{j 2}=\cdots=k_{j n}$ or 2) $k_{j 1} \neq k_{j 2} \neq \cdots \neq k_{j n}$.

Let study possible geometry of shapes, taking into account additional conditions:

a) if $k_{j 1}=k_{j 2}=\cdots=k_{j n}=k$, we will obtain $n$-parallelepipeds, where

$$
x_{01}+x_{02}+\cdots+x_{0 n}=p k^{n} x_{01} x_{02} \ldots x_{0 n} \sum_{i=1}^{n} x_{0 i}=p k^{n} \prod_{i=1}^{n} x_{0 i} \text {; }
$$$$
x_{j 1}+x_{j 2}+\cdots+x_{j n}=p k^{n} x_{j 1} x_{j 2} \ldots x_{j n} \quad \sum_{l=1}^{n} x_{j i}=p k^{n} \prod_{i=1}^{n_{i}} x_{j i} \text {, }
$$$$
x_{j 1}+x_{j 2}+\cdots+x_{j n}=p k^{n} x_{j 1} x_{j 2} \ldots x_{j n} \sum_{l=1}^{n} x_{j i}=p k^{n} \prod_{i=1}^{n_{i}} x_{j i},
$$

then $\frac{x_{j 1}+x_{j 2}+\cdots+x_{j n}}{x_{01}+x_{02}+\cdots+x_{0 n}}=\frac{x_{j 1} x_{j 2} \ldots x_{j n}}{x_{01} x_{02} \cdots x_{0 n}} \quad \frac{\sum_{i=1}^{n} x_{j i}}{\sum_{i=1}^{n} x_{0 i}}=\frac{\prod_{t=1}^{n} x_{j i}}{\prod_{i=1}^{n} x_{0 i}}$

That is to say, we may establish correlations (proportions) between relative sums of the indicators and products of the indicators in the general indicator $\mathrm{A}$.

b) if $k_{j i} 1 \neq k i_{2}\left(\exists i_{1} \neq i_{2}: i_{1}, i_{2} \in\{1,2, \ldots, n\}\right)$, we will obtain $n$ - parallelepipeds $P 0, P 1, \ldots, P m$ with sizes of one-dimensional edges $k_{j i x} j i, j=0,1,2, \ldots, m ; i=1,2, \ldots, n$. Their density is determined by the following conditions:

$$
\begin{gathered}
\frac{x_{01}+x_{01}+\cdots+x_{0 n}}{k_{01} x_{01} k_{02} x_{02} \cdots k_{0 n} x_{0 n}}=\frac{x_{j 1}+x_{j 2}+\cdots+x_{j n}}{k_{j 1} x_{j 1} k_{j 2} x_{j 2} \cdots k_{j n} x_{j n}}=\cdots= \\
=\frac{x_{m 1}+x_{m 2}+\cdots+x_{m n}}{k_{m 1} x_{m 1} k_{m 2} x_{m 2} \cdots k_{m n} x_{m n}}
\end{gathered}
$$

Hence

$$
\frac{x_{j 1}+x_{j 1}+\cdots+x_{j n}}{x_{01}+x_{01}+\cdots+x_{6 r}}=\frac{k_{j 1} x_{j 1} k_{j 2} x_{j 2} \ldots k_{j n} x_{j n}}{k_{01} x_{01} k_{02} x_{02} \ldots k_{0 n} x_{0 n}}
$$

In other words, we may establish correlations (proportions) between the relative indicators of a $j$ functional component of economic security and the relative products of edges of a $j n$-parallelepiped, which geometrically describes the general level of economic security of a company $A$. Thus, the same sum may be presented in the form of different geometric shapes, i.e. we can identify indicators for each functional component of economic security carrying the same "value". Such procedure supplements information, which discloses "qualitative" (verbal) distinctions of the functional components of economic security at a company and (or) their indicators. Geometry is determined by the value $k_{j i} x_{j i}-$ 
sizes of edges in terms of arbitrary units, $j=0,1,2, \ldots, m ; i=1,2, \ldots, n$.

Therefore, the economic problem concerned with the formation of the database used to assess economic security of retail enterprises may be reduced to the following mathematical problem.

Mathematical problem. There is a need to position the $n$-parallelepipeds $P j$ (data are formed according to the functional components of economic security at companies) with the volumes $V j$ in the $n$-parallelepiped $P 0$ (the general level of security at a retail company) with the volume $V_{A}$ in such a way that $V_{A}-\sum m_{j=1} V_{j} \rightarrow \min$.

That is to say, it is necessary to minimize an area $D=P_{0} / \sum m_{j} \underline{P}_{j}$ under the condition that $P_{j} \subset P_{0}, j=$ $1,2, \ldots, m$, int $P_{S} \cap$ int $P_{r}=\emptyset, s=1,2, \ldots, m-1 ; r=s+1, \ldots, m$. This condition is equivalent to another one: to maximize a fill ratio $K=\left(\sum_{j=1}^{m} V_{j}\right) / V_{A}$ of the area $D$.

To express $n$-parallelepipeds in the numerical form, the authors have developed an algorithm for calculation of coefficients $k j i, i=1,2, . ., n ; j=1,2, \ldots, m$, when $n=3, j=2$.

Let consider two parallelepipeds: $P 1$ with sizes (edges) $\left[k 11 x_{11}, k_{12} x_{12}, k_{13} x_{13}\right]$ and $P_{2}$ with sizes (edges) [ $k_{2} 1 x_{21}$, $k 22 \times 22, k 23 \times 23]$.

Coefficients $k j i, i=1,2,3 ; j=1,2$ meet the following conditions:

1) $k j i>0, i=1,2,3 ; j=1,2$.

$p=\frac{\sum_{i=1}^{3} x_{1 i}}{\sum_{i=1} k_{1 i} x_{1 i}}=\frac{\sum_{i=1}^{3} x_{2 i}}{\sum_{i=1} k_{2 i} x_{2 i}}, \quad p=p_{A}=\frac{\sum_{\text {where }}^{3} x_{o i}}{\sum_{i=1} k_{0 i} x_{0 i}}=\operatorname{const}$

3) let $d 1$ and $d_{2}$ be diagonals of parallelepipeds $P_{1}$ and $P_{2}$ respectively. Hence, the parallelepiped has the following properties:

4)

$$
d_{1}^{2}=\left(k_{11} x_{11}\right)^{2}+\left(k_{12} x_{12}\right)^{2}+\left(k_{13} x_{13}\right)^{2}
$$

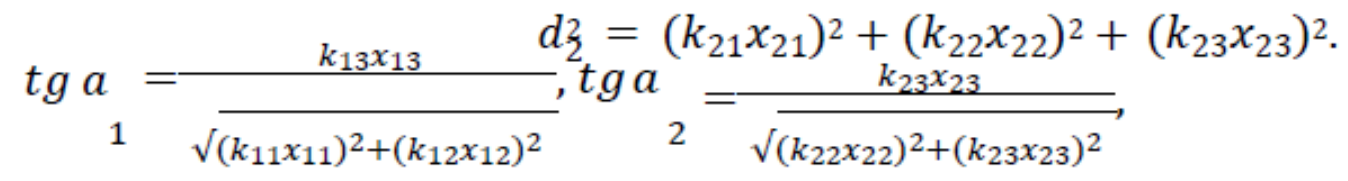

where a1 ( a2 ) - an angle between the diagonal $d_{1}\left(d_{2}\right)$ and its projection of the plane of the base.

The above-mentioned terms lead to the formation of a certain system. Solving this system (under certain additional conditions) enables to compute unknown coefficients $k j i, i=1,2,3 ; j=1,2$.

Let assume that we have determined sizes $\left[k j 1 x_{j 1}, k j 2 x_{j} 2, \ldots, k j n x_{j n}\right], j=0,1,2, \ldots m$, of the $n$-parallelepipeds $P 0$, $P 1, \ldots, P m$ and the current balance in case of $\mathrm{P} A=\mathrm{P} j$.

Applying the methods of positioning $n$-parallelepipeds proposed by foreign scientists E. Mukhacheva, V. Kartak, L. Lins, S. Lins, and R. Morabito, we may obtain a tight package of the $n$-parallelepipeds $P j, j=1,2, \ldots, m$, which will correspond to a formed set of data used to assess a level of economic security by its functional components, in the $n$-parallelepiped $P 0$, which describes the general level of economic security of a retail company (Mukhacheva and Kartak, 2000; Lins et al., 2002).

The optimal sequence of the formation of the database used to assess economic security of a company by each functional component $a_{j}, j=1,2, \ldots, m$ conforms to the obtained sequence of positioning the $n$ - parallelepipeds. Geometric features of these $n$-parallelepipeds are output data for making decisions regarding the formation of the database and conducting an assessment based on this database.

It is expedient to consider the above-mentioned "floating ruler" case. The economic interpretation of such case implies a rapid change of several evaluative indicators by the functional component of economic security. Let 
consider a case where at least one of the indicators in a particular $r$ component changes, $r \in\{1,2, \ldots, m\}$.

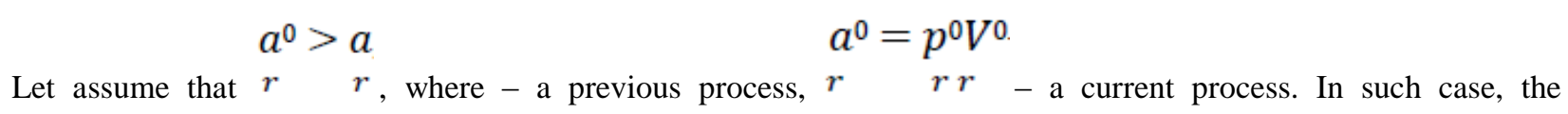
following changes can be observed:

1) $\begin{aligned} p^{0}= \\ r\end{aligned} \underset{r}{p} \Rightarrow V^{0}>p$

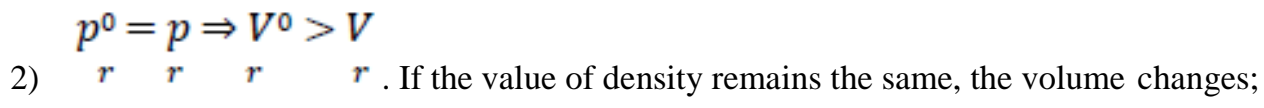

$\left(V^{0} \neq V\right) \wedge\left(\underset{r}{\left(p^{0} \neq p\right.}\right)$

3) $\begin{array}{rrrrr}r & r & r & r\end{array}$. That is to say, both the density and volume change.

Existence of such changes stipulates the necessity for revision of the formed database for assessing economic security of a company. In the first case, a change of the density value $\left(p_{r} \neq p_{A}\right)$ gives rise to a need for the formation of a new database. In the second case, there is a need to reduce or add data (indicators). The third case leads to revision of the whole database and division of the indicators by the functional components of economic security of a retail company.

\section{Conclusion}

To optimize the formation of the database used to assess a level of economic security at a retail company, the authors have proposed the algorithm of mathematical calculations and gradual actions. Application of the proposed methodical instrument facilitates solving the economic problem through compiling the optimized balance of the evaluative indicators in terms of the same units of measurement and division of the indicators by the economic essence according to the functional components of economic security. In addition, the author have solved the problem related to division of the indicators, which are expressed in the same mathematical form but have different economic meanings.

The developed methodical instrument may be used in the formation of the database for assessing economic security of retail companies in order to enhance quality of the database underling the process of analysing.

\section{Acknowledgement}

The authors would like to express their deepest appreciation to the academic personnel of the Department of Finances and Credit, Kharkiv National University of Construction and Architecture, Department of Economics of Catering and Trade Enterprises, and Department of Foreign Trade and Tourism, Kharkiv State University of Food Technology and Trade for providing facilities to conduct this research.

\section{Conflict of interest}

The author declares that there is no conflict of interests regarding the publication of this manuscript.

\section{References}

Babenko, V. A. (2013). Formation of Economic-Mathematical Model for Process Dynamics of Innovative Technologies Management at Agroindustrial Enterprises. Actual Problems of Economics, 139(1), 182-186.

Babenko, V., Chebanova, N., Ryzhikova, N., Rudenko, S., \& Birchenko, N. (2018). Research into the Process of Multi-Level Management of Enterprise Production Activities with Taking Risks into Consideration. $\begin{array}{lllll}\text { Eastern-European Journal of Enterprise Technologies, } & 3(91),\end{array}$ https://doi.org/10.15587/1729-4061.2018.123461

Chub, I. A., \& Novozhylova, M. V. (2002). Analiticheskoie opisaniie usloviia prinadlezhnosti obiekta s izmeniaiemymi metricheskimi kharakteristikami oblasti razmeshcheniia [Analytical Description of the Condition of Belonging Object Having the Variable Metric Characteristics to a Stock Sheet]. Information Processing Systems, 6, 248-251. Retrieved from www/hups.mil.gov.ua

Datskiv, R. M. (2004). Ekonomichna bezpeka u hlobalnomu vymiri [Economic Security on a Global Scale]. Actual Problems of Economics, 7(37), 143-153.

Dovbnia, S. B., \& Hichova, N. Y. (2008). Diahnostyka rivnia ekonomichnoi bezpeky pidpryiemstva [Diagnosing a Level of Economic Safety of an Enterprise]. Finance of Ukraine, 4, 88-97. 
Gontareva, I., Murenets, I., Kurmaiev, P., Podzihun, S., \& Dorokhov, O. (2018). Functionality and Quality Management of Transformation of Capital Forms at an Enterprise. TEM Journal, 7(3), 597-606. https://doi.org/10.18421/TEM73-16

Greer, B. (1986). European Economic Security. In St. Flanagan, \& F. Hampson (Eds.), Securing Europe`s Future. London, Routledge.

Hil, N. I., Yakovlev, S. V., \& Novozhylova, M. V. (1995). Elementy teorii heometricheskoho proektirovaniia [Elements of the Geometric Projection Theory]. Kyiv, Naukova Dumka.

Hrebennik, I. V., \& Romanova, T. Ye. (2002). The Interval Hyperplane in the Space n s IR. Problems of Mechanical Engineering, 3(5), 52-56.

Iliashenko, S. N. (2003). Sostavliaiushchiie ekonomicheskoi bezopasnosti predpriiatiia i podkhody k ikh otsenke [Components of Enterprise Economic Security and Approaches to Assessing These Components]. Actual Problems of Economics, 3(21), 12-19.

Komyak, V. M., Putyatin, V. P., \& Komyak, V. V. (2012). Ob odnoj zadache razbienija oblasti na podoblasti [A Problem of Cutting Area on Sub Areas]. Herald of the Kherson National Technical University, 45, 171-175.

Kovalenko, V. V. (2016). Metodychni pidkhody shchodo diahnostyky rivnia ekonomichnoi bezpeky pidpryiemstv [Methodical Approaches for Diagnosing a Level of Economic Safety of Enterprises]. Young Scientist, 4, 8-88.

Lins, L., Lins, S., \& Morabito, R. (2002). An N-Tet Graph Approach for Non-Guillotine Packing of N- Dimensional Boxes into an N-Container. European Journal of Operational Research, 141, 421-439.

Malyarets, L., Draskovic, M., Babenko, V., Kochuyeva, Z., \& Dorokhov, O. (2017). Theory and Practice of Controlling at Enterprises in International Business. Economic Annals-XXI, 165(5-6), 90-96. https://doi.org10.21003/ea.V165-19

Mukhacheva, E. A., Kartak, V. M., \& Vasilyeva, L. I. (2000). Exact Algorithms for Solving N- Dimensional Bin-Packing Problem. The Annual Meeting "Informs - 2000", San Antonio.

Novozhylova, M. V., \& Chernomorets, A. A. (1992). Ob odnom sposobe poiska optimalnoho razmeshcheniia hiperparallelepipedov [About One Method for Searching Optimal Positioning Parallelepipeds]. Preprints of the National Academy of Sciences of Ukraine. The Institution of Problems of Mechanical Engineering, 365, 27.

Novozhylova, M. V., Yevseieva, L. H., \& Romanova, T. Ye. (2004). Osnovnaia optimizatsionnaia zadacha heometricheskoho proektirovaniia v intervalnom vide [A Basic Optimization Problem of Geometric Design in the Interval Space]. Radio Electronics, Computer Science, Control, 2, 68-72.

Pohozhykh, M. I., \& Safronova, M. S. (2018). Metod formuvannia bazy danykh dlia zadachi optymalnoho planuvannia diialnosti pidpryiemstva [The Method for the Formation of a Database for a Problem of Optimal Planning Activity of an Enterprise]. Economic Strategy and Perspectives of the Development of Trade and Services Sphere, 1(27), 56-66.

Putiatin, V. P., \& Elkin, A. B. (2007). Kombinatornyie apparatnyie modeli zadach heometricheskoho proektirovaniia [Combinatorial Hardware Models for Problems of Geometric Projection]. Information Processing Systems, 3(61), 86-91.

Rozenfeld, B. A. (1966). Mnohomernye prostranstva [Multidimensional Spaces]. Moscow, Nauka.

Sadkovyi, V. P., Komyak, V. M., \& Sobol, O. M. (2008). Racional'ne rozbyttja mnozhyn pry terytorial'nomu planuvanni v sferi cyvil'nogo zahystu [Rational Cutting the Sets for Spatial Planning in the Field of Civil Defense]. Kharkiv, Lihtar.

Shorikov, A. F., \& Babenko, V. A. (2014). Optimization of Assured Result in Dynamical Model of Management of Innovation Process in the Enterprise of Agricultural Production Complex. Economy of Region, 1, 196-202. https://doi.org/10.17059/2014-1-18

Shumilo, O. S. (2015). Skladovi ekonomichnoi bezpeky pidpryiemstv rozdribnoi torhivli [Components of Economic Security of Retail Companies]. Economic Space, 100, 205-218.

Stoian, Yu. H., Romanova, T. Ye., \& Yevseieva, L. H. (1998). Kombinatornaia optimizatsionnaia zadacha razmeshcheniia priamouholnikov $\mathrm{s}$ uchetom pohreshnostei iskhodnykh dannykh [The Combinatorial Optimization Problem of Positioning Rectangles, Taking into Account Errors of Raw Data]. Reports of the National Academy of Sciences of Ukraine, Series A, 9, 114-120. 
Stoyan, Y. G., \& Yakovlev, S. V. (1986). Matematicheskie modeli i optimizatsionnyie metody heometricheskoho proektirovaniia [Mathematical Models and Optimization Methods of Geometric Design]. Kiev, Naukova Dumka.

Stoyan, Y. G., \& Yaskov, G. N. (2000). Peculiarities of a mathematical model of optimization of a placement of circles and method of searching for an approximation to a global minimum. Reports of the National Academy of Sciences of Ukraine, 1, 86-90.

Tkachenko, A. M., \& Reznikov, O. L. (2010). Otsinka rivnia ekonomichnoi bezpeky pidpryiemstva [Evaluating a Level of Economic Security of an Enterprise]. Herald of the Economic Sciences of Ukraine, 1(17), 101-106.

Totsenko, V. H., Tsyhanok, V. V., \& Kachanov, P. T. (2002). Pidtrymka pryiniattia rishennia shchodo vyboru metodu ekspertnoho otsiniuvannia [Supporting Decision-Making on Selecting a Method for Expert Evaluation]. System Research and Information Technologies, 4, 52-60.

Verkhoturov, M. A., \& Petrenko, S. V. (2005). Ob odnom podkhode k nakhozhdeniiu lokalnoho ekstremuma zadachi razmeshcheniia nevypuklykh oriientirovannykh mnohouholnykov v polubeskonechnoi polose [About One Approach to Finding a Local Extremum for a Problem of Positioning Non-convex Oriented Polygons in a Semi-infinite Strip]. The Inter-university Collection of Scientific Papers, 7-18.

Vnukova, N. M., \& Smoliak, V. A. (2002). Bazova metodyka otsinky ekonomichnoho ryzyku pidpryiemstv [Basic Tools for Evaluating an Economic Risk of an Enterprise]. Finance of Ukraine, 10, 15-21.

Yevseieva, L. H., Romanova, T. Ye., \& Sysoieva, Yu. A. (1999). Osobennosti kombinatornoi optimizatsionnoi zadachi razmeshcheniia intervalnykh priamouholnykov [Peculiarities of a Combinatorial Optimization Problem of Positioning Interval Rectangles]. Radioelectronics \& Informatics, 3, 48-50. 